\title{
The Art of Detecting Antibodies against Factor VIII
}

\author{
Andreas Tiede $^{1}$ Lorenzo Alberio ${ }^{2}$ \\ ${ }^{1}$ Department of Hematology, Hemostasis, Oncology, and Stem Cell \\ Transplantation, Hannover Medical School, Hannover, Germany \\ ${ }^{2}$ Service et Laboratoire Central d'Hématologie, Centre Hospitalier \\ Universitaire Vaudois, Lausanne, Switzerland \\ Hämostaseologie 2020;40:485-490.
}

Address for correspondence Andreas Tiede, MD, PhD, Department of Hematology, Hemostasis, Oncology, and Stem Cell Transplantation, Hannover Medical School, Carl Neuberg Str. 1, 30625 Hannover, Germany (e-mail: tiede.andreas@mh-hannover.de).

\author{
Abstract \\ Keywords \\ - coagulation \\ - assay \\ - inhibitor \\ - autoantibodies \\ - Bethesda assay

Zusammenfassung
Schlüsselwörter
- Gerinnung
- Laborteste
- Hemmkörper
- Autoantikörper
- Bethesda-Test

Antibodies against factor VIII (FVIII) can be detected based on their ability to neutralize the procoagulant activity of FVIII (neutralizing antibodies, inhibitors), or based on their specific binding capacity to FVIII protein. This article reviews the available assays and their clinical interpretation in patients with congenital and acquired hemophilia.

Antikörper gegen Faktor VIII (FVIII) können anhand ihrer neutralisierenden Funktion gegenüber der prokoagulatorischen FVIII Aktivität oder anhand ihrer Bindung an das FVIII-Protein nachgewiesen werden. Dieser Artikel gibt einen Überblick über die verfügbaren Laborteste und ihre klinische Interpretation bei Patienten mit angeborener oder erworbener Hämophilie.

\section{Introduction}

Antibodies against coagulation factor VIII (FVIII) develop in patients with congenital and acquired hemophilia A. They are called inhibitors, if anti-FVIII antibodies neutralize the procoagulant capacity of FVIII. Anti-FVIII antibodies can be alloantibodies (in patients with congenital hemophilia A after exposure to therapeutic FVIII protein) or autoantibodies (in patients with acquired hemophilia $A$ ).

The detection of anti-FVIII antibodies is important to diagnose acquired hemophilia and to detect neutralizing inhibitors in patients with congenital hemophilia A under treatment with FVIII products. Several methods exist to detect neutralizing antibodies based on their functional capacities, and to detect FVIII-binding antibodies (FVIII:Abs) that may or may not neutralize FVIII activity and can interfere with its pharmacokinetics.
This article provides an overview on the methods to detect antibodies against FVIII, reviews potential pitfalls, and supports the clinical interpretation of results.

\section{Nomenclature of Assays for FVIII Activity and Antigen}

The International Society on Thrombosis and Haemostasis endorsed a nomenclature in 1985, denoting the FVIII coagulant activity as "FVIII:C."1 At that time, FVIII activity was predominantly measured by clotting assays based on the activated partial thromboplastin time (APTT). Today, different types of chromogenic substrate assays of FVIII activity have become popular, even for inhibitor assays. To avoid confusion, the designation and abbreviation of assays discussed in this article are provided in -Table 1. received

May 15, 2020

accepted after revision

July 20, 2020

\author{
(c) 2020 Georg Thieme Verlag KG \\ Stuttgart · New York \\ DOI https://doi.org/ \\ 10.1055/a-1223-3353. \\ ISSN 0720-9355.
}


Table 1 Nomenclature of assays of FVIII activity and inhibitor detection as used in this article

\begin{tabular}{|c|c|c|}
\hline Abbreviation & Definition & Notes \\
\hline FVIII:C & FVIII coagulant activity & Generic term for any FVIII activity assay \\
\hline FVIII:CBA & $\begin{array}{l}\text { FVIII coagulant activity in one-stage } \\
\text { clot-based assay (CBA) }\end{array}$ & $\begin{array}{l}\text { Traditional standard for diagnosis and } \\
\text { monitoring of hemophilia } \\
\text { Artificially high results in samples with emicizumab }\end{array}$ \\
\hline FVIII:CSB & $\begin{array}{l}\text { FVIII coagulant activity in chromogenic } \\
\text { substrate (CS) assay with bovine } \\
\text { (B) components }\end{array}$ & $\begin{array}{l}\text { Insensitive to emicizumab: useful for measuring human } \\
\text { FVIII activity in samples with emicizumab } \\
\text { Porcine recombinant FVIII activity will be underestimated }\end{array}$ \\
\hline FVIII:CSH & $\begin{array}{l}\text { FVIII coagulant activity in CS assay } \\
\text { with human }(\mathrm{H}) \text { components }\end{array}$ & Useful for monitoring emicizumab concentration \\
\hline NBA & $\begin{array}{l}\text { Nijmegen-modified Bethesda assay } \\
\text { using clot-based assay }\end{array}$ & $\begin{array}{l}\text { Gold standard for FVIII inhibitors, but cannot be used } \\
\text { in samples with emicizumab }\end{array}$ \\
\hline NBA:CSB & $\begin{array}{l}\text { Nijmegen-modified Bethesda assay using } \\
\text { CS assay with bovine (B) components }\end{array}$ & Useful for detecting inhibitors in samples with emicizumab \\
\hline NBA:POR & $\begin{array}{l}\text { Nijmegen-modified Bethesda assay using } \\
\text { recombinant porcine (POR) FVIII as a substrate }\end{array}$ & $\begin{array}{l}\text { Useful to measure cross-reactivity of anti-human FVIII } \\
\text { antibodies with susoctocog alfa } \\
\text { FVIII:CBA should be used for detection. }\end{array}$ \\
\hline FVIII:Ab & Immunoassay for FVIII binding antibodies. & $\begin{array}{l}\text { Useful for confirming anti-FVIII antibodies in doubtful } \\
\text { inhibitor assays. Isotype/subclass should be reported. }\end{array}$ \\
\hline
\end{tabular}

Abbreviation: FVIII, factor VIII.

\section{Bethesda Assay}

\section{Principle}

This assay detects neutralizing antibodies (inhibitors) against FVIII:C. ${ }^{2}$ The gold standard is the Nijmegen-modified Bethesda assay (NBA). Patient plasma, or serial dilutions thereof, is mixed with FVIII-containing standard human plasma (SHP) and incubated at $37^{\circ} \mathrm{C}$ for 2 hours. The incubation is important because inhibitors against FVIII: $\mathrm{C}$ are temperature- and timesensitive. After incubation, the FVIII:C residual activity (RA) will be determined and compared with that of a control

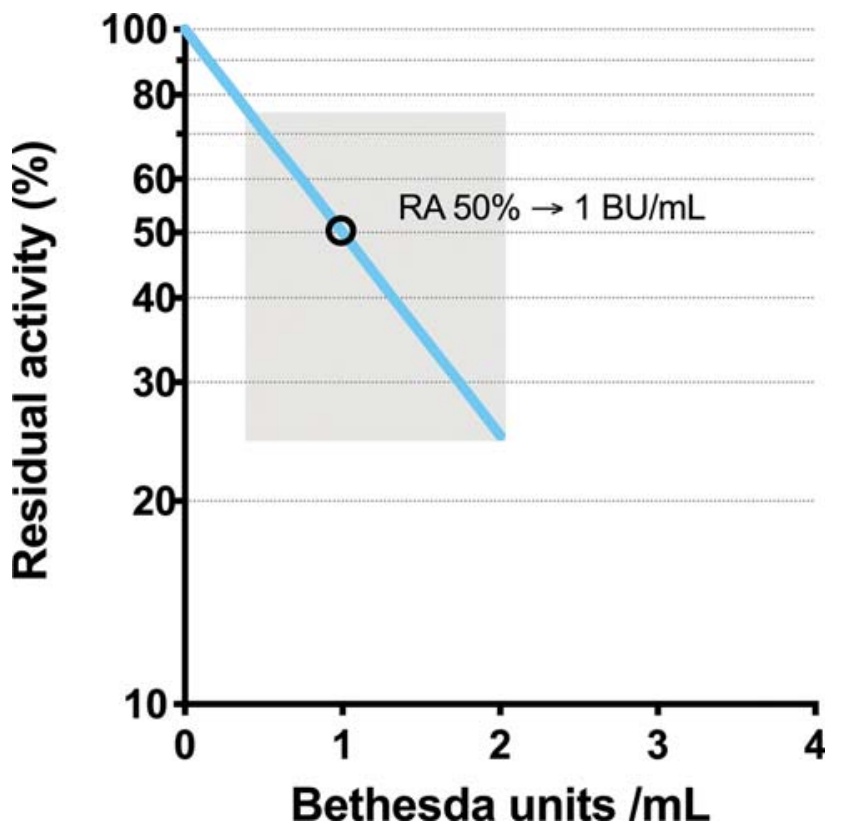

Fig. 1 Nomogram for inhibitor quantification. mixture of SHP with inhibitor-free FVIII-deficient plasma. 1 Bethesda unit (BU) is defined as the amount of inhibitor that will neutralize 50\% of FVIII:C in SHP. A window defined by the RA range of 25 to $75 \%$ is recommended to determine inhibitor strength ( - Fig. 1). Outside this window, samples will be diluted, and the dilution that gives an RA nearest to $50 \%$ (and within the range of 25-75\%) will be used to determine the inhibitor strength.

\section{Method}

An overview on the method is provided in - Table 2. In the classical version of the Bethesda assay, patient samples had been diluted in buffer and unbuffered normal plasma was used as a source of FVIII. ${ }^{3}$ The Nijmegen modification, introduced with the NBA to improve specificity at low inhibitor titers, contained the following: ${ }^{4}$

- Sample diluent: FVIII-deficient plasma instead of diluent buffer.

- FVIII source: buffered SHP (e.g., 0.1 M imidazole, pH 7.4) instead of unbuffered plasma.

Instead of FVIII-deficient plasma, 4\% albumin has been suggested. $^{5}$

\section{Type 1 versus Type 2 Inhibitors}

The principle of inhibitor quantification in diluted samples, later on multiplied by the dilution factor, was originally developed for the so-called type 1 inhibitors that typically occur in patients with congenital hemophilia A. Type 1 inhibitors are characterized by a log-linear relationship between dilution and RA, whereas type 2 inhibitors are not ${ }^{6}$ (-Fig. 2). The latter can be quantified very roughly only. Sometimes, several dilutions are very close to RA 50\% in type 2 inhibitors, yielding very unreliable results. Heat inactivation does not 
Table 2 Nijmegen-modified Bethesda assay

\begin{tabular}{|c|}
\hline Sample dilution \\
\hline Prepare serial dilution of patient plasma in FVIII-deficient plasma \\
\hline - Dilution factor 1 (undiluted): patient plasma (0.2 mL) \\
\hline - Dilution factor 2: patient plasma $(0.2 \mathrm{~mL})+$ FVIII-deficient plasma $(0.2 \mathrm{~mL})$ \\
\hline - Dilution factor 4: previous dilution $(0.2 \mathrm{~mL})+$ FVIII-deficient plasma $(0.2 \mathrm{~mL})$ \\
\hline - Etc. \\
\hline Control sample: FVIII-deficient plasma (0.2 mL) \\
\hline Mixing and incubation \\
\hline Add $0.2 \mathrm{~mL}$ SHP to each dilution and to the control sample \\
\hline Cap tubes, mix, and incubate at $37^{\circ} \mathrm{C}$ for 2 hours \\
\hline FVIII:C assay \\
\hline Measure FVIII:C in each sample including the control sample \\
\hline - FVIII:CBA in original NBA \\
\hline - FVIII:CSB in NBA:CSB (insensitive to emicizumab) \\
\hline Perform assay immediately \\
\hline Consider using a chromogenic assay with bovine components, if patient on emicizumab \\
\hline Results and interpretation \\
\hline Express RA by dividing the FVIII:C of each sample by FVIII:C of control \\
\hline Select dilution that gives RA nearest to $50 \%$ and within the range $25-75 \%$ \\
\hline Determine inhibitor units from nomogram (-Fig. 1) or formula: $c_{\text {inh }}[B U / m L]=\left(2-\log _{10} R A\right) / \log _{10} 2$ \\
\hline Multiply by dilution factor to give final result \\
\hline
\end{tabular}

Abbreviations: FVIII, factor VIII; NBA, Nijmegen-modified Bethesda assay; RA, residual activity; SHP, standard human plasma.
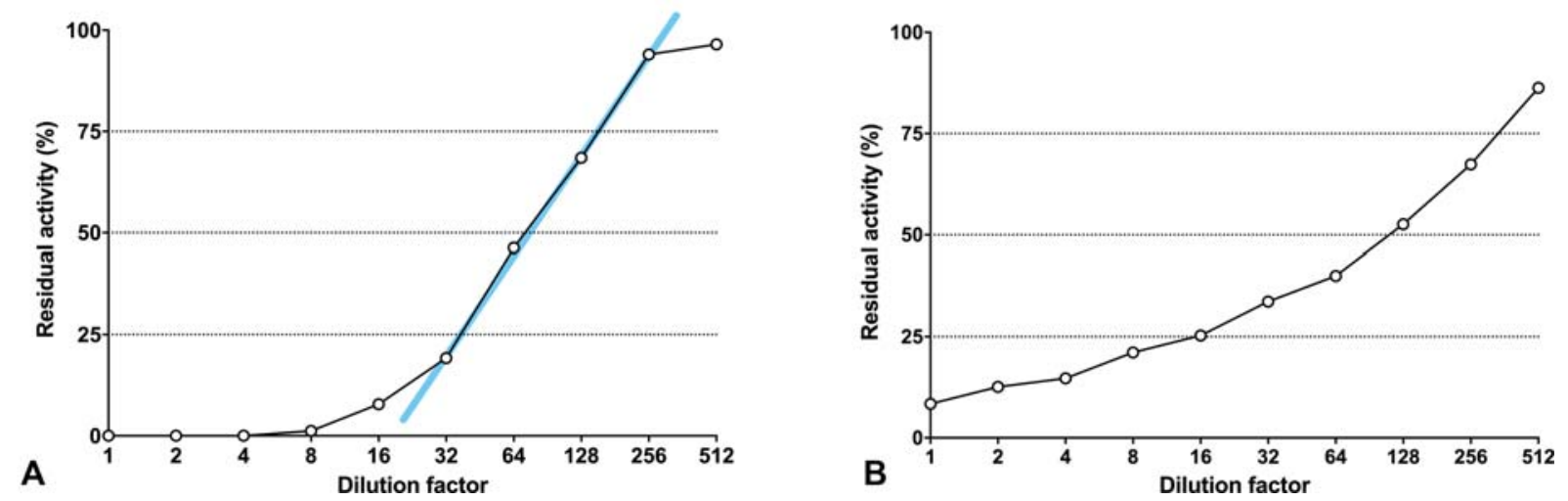

Fig. 2 Type 1 versus type 2 inhibitors. (A) Typical features of type 1 inhibitors are absent residual activity (RA) at low dilution factors and a loglinear relationship between dilution and RA as indicated by the blue line. (B) Typical features of type 2 inhibitors are measurable RA at low dilution and lack of a log-linear relationship between dilution factor and RA.

reliably solve the problem of type 2 inhibitors (personal experience), and so it is very important to qualify the test result by denoting a type 2 inhibitor as such.

\section{Residual FVIII:C in Sample}

If the test plasma contains significant amounts of FVIII:C (typically more than $5 \mathrm{IU} / \mathrm{dL}$ or $5 \%$ ), the inhibitor will be underestimated by the NBA. Both in vivo absorption of inhibitors and intra-assay underestimation due to FVIII:C in the sample can occur. The latter can be solved in part by heat inactivation at $56^{\circ} \mathrm{C}$ for 90 minutes. ${ }^{7,8}$ Large amounts of FVIII protein will, however, still neutralize some of the inhibitor capacity in the sample by absorption, and so samples for inhibitor quantification should ideally be drawn after washout.

\section{Emicizumab in Sample}

Emicizumab is a bispecific antibody that can replace the role of activated FVIII in the coagulation cascade by positioning factors IXa and X against each other, so that IXa can activate 
$\mathrm{X} .{ }^{9}$ Unlike natural FVIII, emicizumab does not require activation by thrombin, and therefore:

- APTT is artificially shortened. ${ }^{10}$

- APTT-based factor assays including FVIII:CBA give falsehigh results. ${ }^{10}$

- The FVIII:CBA-based NBA is false-negative.

A guideline for using coagulation tests in emicizumabtreated patients has been issued by the United Kingdom Haemophilia Centre Doctors' Organization. ${ }^{11}$ NBA:CSB can be used if samples contain emicizumab because FVIII:CSB contains bovine proteins and is insensitive to the drug. ${ }^{12}$ Alternatively, anti-idiotypic antibodies can be used to neutralize emicizumab in the sample. ${ }^{13}$

\section{Other Conditions that Interfere with the Bethesda Assay} Pharmacological anticoagulants that prolong the APTT can cause false-positive results in the NBA and should be avoided at the time of sampling. ${ }^{14}$ More difficult to assess is the lupus anticoagulant (LA) that can sometimes interfere with the Bethesda assay. A negative dilute Russell's viper venom time (DRVVT) or DRVVT-based LA ratio helps to exclude LA in most cases. However, $22 \%$ of patients with congenital hemophilia A also had an increased LA ratio in a DRVVT-based assay. ${ }^{15}$ Therefore, LA does not exclude a FVIII inhibitor.

\section{Modified Bethesda Assay with Chromogenic FVIII:C Detection}

NBA:CSB is a modification of the NBA using FVIII:CSB to measure RA after incubation ( - Table 1 ). NBA:CSB showed an overall good correlation with results from the NBA, could eliminate some low-titer, false-positive results, ${ }^{16}$ is expected to be less sensitive to LA, ${ }^{17}$ and is insensitive to the effects of emicizumab. ${ }^{12}$ Imidazole-buffered bovine serum albumin as a sample diluent may improve specificity as compared with FVIII-deficient plasma. ${ }^{18}$

\section{Inhibitors against Recombinant Porcine FVIII (Susoctocog Alfa)}

Susoctocog alfa is a recombinant porcine FVIII (rpFVIII) molecule that is used to treat bleeds in acquired hemophilia $\mathrm{A}$ and is also under investigation for patients with congenital hemophilia A and inhibitors. Antibodies against human FVIII usually react much less with rpFVIII. However, $44 \%$ of patients with acquired hemophilia show at least some degree of cross-reactivity, ${ }^{19}$ and some patients will develop de novo cross-reactivity during treatment. $^{20}$

NBA:POR is a modified NBA using rpFVIII laboratory standard (provided by the manufacturer of susoctocog alfa) instead of SHP as a FVIII source. ${ }^{19}$ The rpFVIII substrate is usually supplied in high concentrations (e.g., $11 \mathrm{U} / \mathrm{mL}$ ) and should be diluted in FVIII deficient plasma. FVIII:CBA is the preferred test for RA determination because chromogenic assays can underestimate the activity of rpFVIII.

\section{Quality Assurance}

Significant interlaboratory variation is observed with inhibitor assays, as reflected by coefficients of variation that are often greater than $30 \%$, and some laboratories fail to detect low-level inhibitors of approximately $1.0 \mathrm{BU} / \mathrm{mL} .^{21}$ The NBA showed a better performance compared with the classical Bethesda assay. Interlaboratory comparisons of NBA:CSB have not been reported.

If interlaboratory quality assurance results show strong deviations from expected results, the local troubleshooting may include the following:

- Compliance with the NBA assay conditions (FVIII-deficient plasma for dilution, incubation time and temperature, and quality of assay for FVIII:C detection).

- Determination of cut point for assessing RA.

- Recognition and interpretation of type 2 inhibitors.

- FVIII:C in control mixture (may affect assay sensitivity).

\section{Detection of FVIII-Binding Antibodies}

\section{Methods}

FVIII:Abs can be detected by the enzyme-linked immunosorbent assay (ELISA). Recombinant FVIII is immobilized to microwells, and diluted plasma (1:100) or diluent control (blank) is incubated for 60 minutes at room temperature. If FVIII:Abs are present, these will bind to the immobilized FVIII. They are detected, after several washing steps, with anti-immunoglobulin $\mathrm{G}$ ( $\mathrm{IgG}$; Fcr) conjugated to horse radish peroxidase and tetramethylbenzidine substrate. ${ }^{22}$

The assay can be performed at a single dilution with reporting:

- Qualitative results based on optical density at $450 \mathrm{~nm}$ $\left(\mathrm{OD}_{450}\right)$ : "positive" $\left(\mathrm{OD}_{450}>0.30\right)$, "grey zone" $\left(\mathrm{OD}_{450}\right.$ $0.15-0.30)$, and "negative" $\left(\mathrm{OD}_{450}<0.15\right)$.

- Quantitative results by using a known anti-FVIII antibody as a calibrator in arbitrary units (AU): "positive" ( $>24 \mathrm{AU} / \mathrm{mL})$, "grey zone" (12-24 AU/mL), and "negative" (<12 AU/mL).

Both assay variants have become commercially available. For research purposes, a three-step methodology has been used consisting of:

- Screening (at dilution of 1:20, with cut-offs determined from negative samples).

- Determination of antibody titer (in 1:2 dilution steps), reporting the highest titer above the cut-off.

- Confirmation with a competition assay. ${ }^{23,24}$

This assay has been used with isotype- or subclass-specific detection reagents for dedicated research questions. Other assays for research use include epitope mapping, ${ }^{25}$ including the mapping of antibodies to functional sites such as the von Willebrand factor-binding site, and affinity measurement. ${ }^{26}$

\section{Interpretation and Limitations}

Low-positive or "grey zone" results are sometimes seen in healthy individuals. ${ }^{27}$ In the absence of reduced FVIII:C, this finding does not establish a diagnosis of hemophilia.

Positive results typically occur in patients with congenital hemophilia A and inhibitors. However, not all FVIII:Abs detected by ELISA are inhibitors. Nonneutralizing FVIII:Abs have been reported in patients just before inhibitors occurred, ${ }^{26}$ 
and also in patients with impaired FVIII pharmacokinetics. ${ }^{27}$ Cut points were calculated to optimize sensitivity (88\%) and specificity (99\%) for IgG1 antibodies with one specific assay but cannot be extrapolated to other assay variants. ${ }^{26}$

Positive results are also expected in patients with acquired hemophilia. In the GTH-AH 01/2010 study, just one out of 102 patients was negative for FVIII:Ab (sensitivity 99\%), and this patient happened to be positive for anti-FVIII IgM. ${ }^{22}$ The specificity, tested in a group of age-matched hospital patients using a cut point of $15 \mathrm{AU} / \mathrm{mL}$, was also $99 \%$. However, given the rarity of acquired hemophilia, the derived positive predictive value $(<1 \%)$ is clinically useless. To make a diagnosis of acquired hemophilia A, a positive result must be combined low FVIII:C results.

Assays allowing for isotype and subclass differentiation have been developed for research use. It was reported that IgG4 antibodies are mainly associated with persistent hightiter inhibitors ${ }^{28}$; IgG1 and IgG3 antibodies are predominantly seen in patients with congenital hemophilia A without inhibitors and can modulate the pharmacokinetics of FVIII ${ }^{27}$; IgA antibodies are associated with relapse and poor prognosis in acquired hemophilia. ${ }^{24}$

\section{Conclusions}

Antibodies against FVIII can be detected in functional assays, based on their ability to neutralize FVIII:C, and in immunoassays, based on binding to FVIII protein. The NBA based on FVIII:CBA is still the gold standard for functional inhibitor detection. However, several pitfalls exist in special patient populations, such as those with LA or under treatment with emicizumab. NBA:CSB is a modification using FVIII:CSB for detection of RA that becomes more popular and may solve some of the preanalytical problems. FVIII:Ab immunoassays can also provide valuable information but have not entered most routine clinical laboratories until now.

Disclosures

None.

\section{Conflict of Interest}

The authors declare, that they have no conflict of interest.

\section{References}

1 Marder VJ, Mannucci PM, Firkin BG, Hoyer LW, Meyer D. Standard nomenclature for factor VIII and von Willebrand factor: a recommendation by the International Committee on Thrombosis and Haemostasis. Thromb Haemost 1985;54(04):871-872

2 Kasper CK, Aledort L, Aronson D, et al. Proceedings: a more uniform measurement of factor VIII inhibitors. Thromb Diath Haemorrh 1975;34(02):612

3 Verbruggen B, van Heerde WL, Laros-van Gorkom BA. Improvements in factor VIII inhibitor detection: from Bethesda to Nijmegen. Semin Thromb Hemost 2009;35(08):752-759

4 Verbruggen B, Novakova I, Wessels H, Boezeman J, van den Berg M, Mauser-Bunschoten E. The Nijmegen modification of the Bethesda assay for factor VIII:C inhibitors: improved specificity and reliability. Thromb Haemost 1995;73(02):247-251

5 Kershaw GW, Chen LS, Jayakodi D, Dunkley SM. Validation of $4 \%$ albumin as a diluent in the Bethesda assay for FVIII inhibitors. Thromb Res 2013;132(06):735-741
6 Gawryl MS, Hoyer LW. Inactivation of factor VIII coagulant activity by two different types of human antibodies. Blood 1982;60(05):1103-1109

7 Batty P, Platton S, Bowles L, Pasi KJ, Hart DP. Pre-analytical heat treatment and a FVIII ELISA improve factor VIII antibody detection in acquired haemophilia A. Br J Haematol 2014;166(06):953-956

8 Boylan B, Miller CH. Effects of pre-analytical heat treatment in factor VIII (FVIII) inhibitor assays on FVIII antibody levels. Haemophilia 2018;24(03):487-491

9 Uchida N, Sambe T, Yoneyama K, et al. A first-in-human phase 1 study of ACE910, a novel factor VIII-mimetic bispecific antibody, in healthy subjects. Blood 2016;127(13):1633-1641

10 Adamkewicz JI, Chen DC, Paz-Priel I. Effects and interferences of emicizumab, a humanised bispecific antibody mimicking activated factor VIII cofactor function, on coagulation assays. Thromb Haemost 2019;119(07):1084-1093

11 Jenkins PV, Bowyer A, Burgess C, et al. Laboratory coagulation tests and emicizumab treatment A United Kingdom Haemophilia Centre Doctors' Organisation guideline. Haemophilia 2020;26(01):151-155

12 Batsuli G, Zimowski KL, Tickle K, Meeks SL, Sidonio RF Jr. Immune tolerance induction in paediatric patients with haemophilia $\mathrm{A}$ and inhibitors receiving emicizumab prophylaxis. Haemophilia 2019;25(05):789-796

13 Nogami K, Soeda T, Matsumoto T, Kawabe Y, Kitazawa T, Shima M. Routine measurements of factor VIII activity and inhibitor titer in the presence of emicizumab utilizing anti-idiotype monoclonal antibodies. J Thromb Haemost 2018;16(07):1383-1390

14 Khandelwal A, Phua CW, Chaudhry HR, et al. Confounding effect of therapeutic protamine and heparin levels on routine and special coagulation testing. Blood Coagul Fibrinolysis 2020;31(01):60-64

15 Tripodi A, Mancuso ME, Chantarangkul V, et al. Lupus anticoagulants and their relationship with the inhibitors against coagulation factor VIII: considerations on the differentiation between the 2 circulating anticoagulants. Clin Chem 2005;51(10): 1883-1885

16 Miller CH, Rice AS, Boylan B, et al; Hemophilia Inhibitor Research Study Investigators. Comparison of clot-based, chromogenic and fluorescence assays for measurement of factor VIII inhibitors in the US Hemophilia Inhibitor Research Study. J Thromb Haemost 2013;11(07):1300-1309

17 de Maistre E, Wahl D, Perret-Guillaume C, et al. A chromogenic assay allows reliable measurement of factor VIII levels in the presence of strong lupus anticoagulants. Thromb Haemost 1998; 79(01):237-238

18 Payne AB, Miller CH, Ellingsen D, Driggers J, Boylan B, Bean CJ. Reagent substitution in the chromogenic Bethesda assay for factor VIII inhibitors. Haemophilia 2019;25(05):e342-e344

19 Türkantoz H, Königs C, Knöbl P, et al. Cross-reacting inhibitors against recombinant porcine factor VIII in acquired hemophilia A: data from the GTH-AH 01/2010 Study. J Thromb Haemost 2020;18 (01):36-43

20 Abou-Ismail MY, Vuyyala S, Prunty J, Schmaier AH, Nayak L. Short term efficacy of recombinant porcine factor VIII in patients with factor VIII inhibitors. Haemophilia 2020

21 Bonar RA, Favaloro EJ, Marsden K. External quality assessment of factor VIII inhibitor assays. Semin Thromb Hemost 2013;39(03): 320-326

22 Werwitzke S, Geisen U, Nowak-Göttl U, et al. Diagnostic and prognostic value of factor VIII binding antibodies in acquired hemophilia A: data from the GTH-AH 01/2010 study. J Thromb Haemost 2016;14(05):940-947

23 Whelan SF, Hofbauer CJ, Horling FM, et al. Distinct characteristics of antibody responses against factor VIII in healthy individuals and in different cohorts of hemophilia A patients. Blood 2013;121 (06):1039-1048

24 Tiede A, Hofbauer CJ, Werwitzke S, et al. Anti-factor VIII IgA as a potential marker of poor prognosis in acquired hemophilia $A$ : 
results from the GTH-AH 01/2010 study. Blood 2016;127(19): 2289-2297

25 Kahle J, Orlowski A, Stichel D, et al. Frequency and epitope specificity of anti-factor VIII C1 domain antibodies in acquired and congenital hemophilia A. Blood 2017;130(06):808-816

26 Hofbauer CJ, Whelan SF, Hirschler M, et al. Affinity of FVIIIspecific antibodies reveals major differences between neutralizing and nonneutralizing antibodies in humans. Blood 2015;125 (07):1180-1188
27 Hofbauer CJ, Kepa S, Schemper M, et al. FVIII-binding IgG modulates FVIII half-life in patients with severe and moderate hemophilia A without inhibitors. Blood 2016;128(02): 293-296

28 Montalvão SA, Tucunduva AC, Siqueira LH, Sambo AL, Medina SS, Ozelo MC. A longitudinal evaluation of anti-FVIII antibodies demonstrated IgG4 subclass is mainly correlated with high-titre inhibitor in haemophilia A patients. Haemophilia 2015;21(05): 686-692 